\title{
CYTOTOXIC ACTIVITY OF IMMUNE CELLS FOLLOWING ADMINISTRATION OF XENOGENEIC CANCER VACCINE IN MICE WITH MELANOMA B-16
}

\author{
N.I. Fedosova*, I.M. Voeykova, O.M. Karaman, T.V. Symchych, \\ G.V. Didenko, G.S. Lisovenko, L.M. Evstratieva, G.P. Potebnya \\ R.E. Kavetsky Institute of Experimental Pathology, Oncology and Radiobiology, NAS of Ukraine, \\ Kyiv 03022, Ukraine
}

\begin{abstract}
Aim: To study the effects of xenogeneic cancer vaccine (XCV) developed on the basis of nervous tissue antigen from rat embryo of late gestation period and protein-containing metabolite of Bacillus subtilis with molecular weight of $70 \mathrm{kDa}$, on specific and unspecific antitumor reactions of cellular and humoral chains of immune system, and to analyze possible mechanisms of its antimetastatic action. Materials and Methods: XCV was administered triply with 3-day intervals after surgical removal of experimental melanoma B-16 in C57Bl/6 mice. Cytotoxic activity (CTA) of splenocytes against target cells K-562 as well as CTA of splenocytes, peritoneal macrophages (PM) and blood serum against melanoma B-16 target cells were determined using MTT test. The content of circulating immune complexes (CIC) in blood serum was evaluated by precipitation reaction. Results: Immunologic effects of XCV vaccination in experimental animals with surgically removed melanoma B-16 in comparison with similarly treated unvaccinated mice were as follows: prevention of medium molecular weight CIC accumulation in blood serum during all observation period, significant increase $(p<0.05)$ of CTA of effectors of unspecific antitumor immunity (natural killer cells NK - by $25.5 \pm 1.7$ vs $12.5 \pm 5.4 \%$, and PM - by $37.3 \pm 0.6$ vs $32.0 \pm 0.9 \%$, respectively) at $37^{\text {th }}$ day after the surgery, and also preservation of functional activity of specific cytotoxic lymphocytes at the level of intact control. Conclusion: The results of the study allow propose that antimetastatic effect of XCV vaccination could be based on increased CTA of NK and PM, and preservation of CTL functional activity at late terms after surgical removal of B-16 primary tumors.
\end{abstract}

Key Words: xenogeneic cancer vaccine, melanoma B-16, natural killer cells, macrophages, cytotoxic lymphocytes, cytotoxic activity, antimetastatic activity.

Skin melanoma still belongs to the most aggressive cancer types, and its incidence is constantly rising worldwide. In 2013, in Ukraine the number of newly registered melanoma cases was 3278 , and the total number of melanoma patients under observation was 25 754. After development of distant metastases an average life expectancy of melanoma patients ranges from 6 to 9 months, and 5-year survival rate is lower than $5 \%$ [1].

The main method of melanoma treatment is its surgical removal while chemotherapy shows low efficacy. Therefore, the search of high effective means for treatment of melanoma patients remains an actual task. Numerous experimental and clinical data evidence on possibility of effective use of immunotherapeutical methods for therapy of melanoma [2-6], in particular, active specific immunotherapy with the use of cancer vaccines [7-9]. The use of vaccines prepared on the basis of xenogeneic tumor cells for melanoma therapy is of special interest because such approach allows significantly increase immunogenecity of cancer vaccine. An induction of specific cellular and humoral immune response against self tumor antigens in the case of use of xenogeneic vaccines

\footnotetext{
Submitted: October 28, 2014.

*Correspondence: E-mail: immunomod@ukr.net Abbreviations used: ADCC - antibody-dependent cell cytotoxicity; CIC - circulating immune complexes; CTAI - cytotoxic activity index; CTL - cytotoxic T-lymphocytes; IFN - interferon; PM peritoneal macrophages; NK - natural killer cell; SB - blood serum; XCV - xenogeneic cancer vaccine.
}

relies on high homology between tumor-associated antigens of man and animals [10-12], in particular those of man and mouse $[13,14]$. The presence of such homology was utilized in some experimental and clinical studies where for melanoma treatment tumor antigens of mouse were used as xenogeneic ones in humans, and vice versa $[15,16]$. In particular, xenovaccination with the use of transplantable human melanoma SK-MEL-28 cells or primary human melanoma cell culture performed at prophylactic regimen with following removal of primary tumor node, resulted in significant suppression of syngeneic melanoma B-16 in mice and reduced lung metastasis. Such vaccination induced an appearance of specific cytotoxic splenocytes, cytotoxic activity (CTA) of which was preserved for 12 weeks $[17,18]$. In other experimental studies, it has been shown that immunization of mice with glycoproteins gp75 and gp100 associated with human melanoma is capable to prevent tumor development $[19,20]$.

At present time, there are the reports on effective therapy of melanoma patients with xenogeneic polyantigenic cancer vaccines composed from melanoma and carcinoma antigens of mouse. Clinical studies have demonstrated an efficacy of such vaccine in the therapy of patients with melanoma or colorectal cancer [21-23].

In the Department of Biotherapeutical Means Construction of R.E. Kavetsky Institute of Experimental Pathology, Oncology and Radiobiology of the NAS of Ukraine (IEPOR NASU) there has been developed a xenogeneic cancer vaccine (XCV) on the basis of ner- 
vous tissue antigen from rat embryo of late gestation period and protein-containing metabolite of Bacillus subtilis with molecular weight of $70 \mathrm{kDa}$ [24]. In experimental melanoma B-16 model there has been shown that such vaccine is highly effective only in the case of surgical removal of the primary tumor node, and then metastasis inhibition index was higher than 95\% [25]. Immunologic mechanisms of antitumor and antimetastatic activity of the vaccine remained unstudied. Therefore, in present work we aimed to evaluate an influence of oncofetal XCV on some indexes of anticancer immunity and to study possible mechanism of antimetastatic action of the vaccine in mice with surgically removed B-16 melanoma.

\section{MATERIALS AND METHODS}

The study has been carried out on female C57BI/6 mice 2.5 months old weighting 18-19 g, bred in the vivarium of IEPOR NASU. The use and care of experimental animals have been performed in accordance with standard international rules on biologic ethics and was approved by Institutional Animal Care and Use Committee [26, 27].

As experimental transplantable tumor model, mouse melanoma B-16 cells obtained from National Bank of Human and Animal Tissues of IEPOR NASU, were used. This strain is maintained by passages in $\mathrm{C} 57 \mathrm{BI} / 6$ mice. For transplantation melanoma cell suspension was prepared by primary tumor trypsinization according to the method [28]. Tumor cells were routinely transplanted in a foot of the right hind leg $\left(2.5 \cdot 10^{5}\right.$ cells/mouse in a volume of $\left.0.05 \mathrm{ml}\right)$. At $18^{\text {th }}$ day after tumor transplantation when the primary tumor reached a diameter of $0.8 \pm 0.2 \mathrm{~cm}$, the surgical removal of a tumor-bearing foot was performed under ethaminal sodium narcosis $(40 \mathrm{mg} / \mathrm{kg}$ ). Three days later the treatment with XCV was initiated. Vaccine $([C]=0.3 \mathrm{mg} / \mathrm{ml}$ ) was injected subcutaneously, triply with 3 days intervals by $0.3 \mathrm{ml} / \mathrm{mouse}([\mathrm{C}]=0.09 \mathrm{mg} /$ animal per 1 injection) with following revaccination with 7 days interval. The control groups were composed from intact animals and unvaccinated animals with melanoma treated by surgical removal of B-16 melanoma.

Immunological examination of the animals was performed at $4^{\text {th }}, 18^{\text {th }}, 32^{\text {nd }}$ and $37^{\text {th }}$ days after the surgery (at $22^{\text {nd }}, 36^{\text {th }}, 51^{\text {st }}$ and $56^{\text {th }}$ days after tumor transplantation, respectively). In control and experimental groups of animals the indexes of cellular and humoral chains of anticancer immunity were analyzed.

The indexes of weight and cellularity of immunocompetent organs were determined by standard method of supravital staining with trypan blue [29].

Cytotoxic activity (CTA) of blood serum (SB) and effector cells (EC) were determined by MTT-test. Spleen lymphocytes (natural killer cells - NK), cytotoxic T-lymphocytes (CTL) and peritoneal macrophages (PM) were used as EC. K-562 cells were used as target cells (TC) for determination of unspecific NK cell cytotoxicity, while melanoma B-16 cells were used as TC for determination of specific cytotoxicity of CTL and PM [30]. In brief, TC were placed in 96-well plate by $2 \cdot 10^{4}$ cells/well in a volume of $0.1 \mathrm{ml}$, and EC were placed by $1 \cdot 10^{5}$ cells/well in a volume of $0.1 \mathrm{ml}$ at the TC/EC ratio of $1: 5$. Plates were incubated for $18 \mathrm{~h}$ in the $100 \%$ humidity atmosphere with $5 \% \mathrm{CO}_{2}$ at $37{ }^{\circ} \mathrm{C}$. Then $0.01 \mathrm{ml}$ of MTT solution per well concentration $5 \mathrm{mg} / \mathrm{ml}$ ("Sigma") was added, and incubation continued for $2 \mathrm{~h}$. Then the plates were centrifuged at $1500 \mathrm{~g}$ for $15 \mathrm{~min}$, twice washed with physiologic solution, and DMSO was added into the well (by $0.14 \mathrm{ml}$ ). Optical density was measured at $\lambda=545 \mathrm{~nm}$ vs $\lambda=630 \mathrm{~nm}$ with the use of micro ELISA reader (StatFax-2100, USA). Each sample was measured in triplicate. CTA index (CTAI, \%) for each EC type was calculated by the formula:

$C T A l_{e c}=\left[1-\left(O D_{e c+t c}-O D_{e c}\right) /\left(O D_{t c}-O D_{\text {blank }}\right)\right] \cdot 100 \%$, where $\mathrm{OD}_{\mathrm{ec}}$ - optical density in the samples with $\mathrm{EC}$; $\mathrm{OD}_{\mathrm{tc}}$ - optical density in the samples with $\mathrm{TC} ; \mathrm{OD}_{\mathrm{ec}+\mathrm{tc}}-$ optical density in experimental series; $\mathrm{OD}_{\text {blank }}$ - optical density in the control well with cultivation medium only.

The level of circulating immune complexes (CIC) in SB of mice was determined in precipitation reaction: high molecular weight $\mathrm{CIC}$ with the use of $3 \%$ polyethylene glycol (PEG), medium molecular weight $\mathrm{CIC}-4.5 \%$ PEG, low molecular weight $\mathrm{CIC}-$ 6\% PEG [31].

For comparison of immunological parameters of animals from experimental and control groups modulation index $\left(\mathrm{Ml}_{e c}\right)$ for each EC type was calculated as follows [32]:

$M l_{e c}=\left[C T A I_{e}(v)-\operatorname{CTAl}_{e}(\mu v) / C T A l_{e}(\mu v)\right] \cdot 100 \%$, where $\mathrm{CTAl}_{e c}(v)$ - index $\mathrm{CTAl}_{e c}$ for the group of vaccinated animals; $\mathrm{CTAl}_{e c}(u v)$ - index $\mathrm{CTAl}_{e c}$ for the group of unvaccinated animals.

At late terms of observation ( $32^{\text {nd }}$ and $37^{\text {th }}$ days after the surgery) Pearson correlation between $\mathrm{Ml}_{e c}$ from vaccinated tumor bearing mice and corresponding metastatic parameters (number and volume of lung metastases) was carried out. Statistical analysis of the data was performed using Student's $t$-criterion (StatSoft STATISTICA 7.0). Values $p<0.05$ were considered statistically significant $[33,34]$.

\section{RESULTS AND DISCUSSION}

In Table 1 there are shown the results of determination of CIC levels in SB of intact animals and unvaccinated or vaccinated mice with surgically removed melanoma B-16. At $18^{\text {th }}$ and $32^{\text {rd }}$ days after the surgery the level of medium molecular weight $\mathrm{CIC}$ in unvaccinated experimental animals was 1.5 times higher than that of intact control. This fact is important as far as it is known that accumulation of immune complexes of low and medium molecular weight capable to bind complement in SB, promotes the development of inflammation and results in negative influence on an organism. It is necessary to note also that increased level of medium molecular weight $\mathrm{CIC}$ in SB evidences on increase of endogenous intoxication level and serves as unfavorable prognostic index in cancer patients $[35,36]$. 
Table 1. Level of CIC in blood serum of intact, vaccinated and unvaccinated mice

\begin{tabular}{|c|c|c|c|}
\hline \multirow[b]{2}{*}{ Animals group } & \multicolumn{3}{|c|}{ Mean CIC, c.u. } \\
\hline & $\begin{array}{l}\text { High molecular } \\
\text { weight }\end{array}$ & $\begin{array}{c}\text { Medium } \\
\text { molecular weight }\end{array}$ & $\begin{array}{c}\text { Low molecular } \\
\text { weight }\end{array}$ \\
\hline Intact & $4.3 \pm 2.3$ & $18.7 \pm 2.4$ & $44.3 \pm 10.9$ \\
\hline \multicolumn{4}{|c|}{$22^{\text {nd }}$ day after tumor transplantation $/ 4^{\text {th }}$ day after the surgery (before vaccination) } \\
\hline Unvaccinated & $6.0 \pm 4.0$ & $17.5 \pm 5.5$ & $48.5 \pm 3.5$ \\
\hline \multicolumn{4}{|c|}{$36^{\text {th }}$ day after tumor transplantation $/ 18^{\text {th }}$ day after the surgery } \\
\hline Unvaccinated & $5.5 \pm 0.5$ & $28.5 \pm 2.5^{1}$ & $56.0 \pm 10.0$ \\
\hline Vaccinated & $1.0 \pm 0.1^{1}$ & $19.5 \pm 2.2^{2}$ & $41.0 \pm 1.0$ \\
\hline \multicolumn{4}{|c|}{$51^{\text {st }}$ day after tumor transplantation $/ 32^{\text {nd }}$ day after the surgery } \\
\hline Unvaccinated & $7.0 \pm 3.0$ & $29.5 \pm 2.3^{1}$ & $68.5 \pm 12.5$ \\
\hline Vaccinated & $8.0 \pm 3.4$ & $22.5 \pm 1.5^{2}$ & $49.5 \pm 13.5$ \\
\hline
\end{tabular}

Note: ${ }^{1} p<0.05$ compared to intact control; ${ }^{2} p<0.05$ compared to unvaccinated animals.

The study of weight and cellularity indexes of immunocompetent organs (spleen, thymus, peripheral lymph nodes) and liver in unvaccinated mice with surgically removed melanoma B-16 has revealed significant increase $(p<0.05)$ of relative weight of spleen and liver, and also total cellularity of spleen compared to intact animals (Table 2). Such changes have been observed during all observation period evidencing on negative influence of residual tumor disease on the organisms of the mice. In vaccinated animals these indexes remained at the level of those in intact animals till $37^{\text {th }}$ day after the surgery and were significantly lower than these in unvaccinated mice at late terms of observation. Relative weight of liver in vaccinated animals was also significantly lower than in unvaccinated mice but was higher than that in intact group (see Table 2). So, the use of XCV prevented an increase of spleen weight and cellularity.

The results of the study of CTA of effectors of specific and unspecific chains of immune system are presented on Figure. NK CTA of unvaccinated mice with surgically removed melanoma B-16 significantly decreased at $4^{\text {th }}$ day after the surgery compared with intact control $(10.5 \pm 1.4 \%$ vs $19.5 \pm 1.7 \%$; $\mathrm{p}<0.05$, respectively), at later terms this index came close to the level of intact animals. At conditions of vaccination there was observed significant increase of CTAl compared with intact mice as well as unvaccinated animals with surgically removed melanoma B-16 during all observation period (Figure, a). Activity of specific cytotoxic lymphocytes in unvaccinated mice compared with intact animals significantly decreased at $32^{\text {nd }}$ day after surgical removal of melanoma
$(15.2 \pm 0.4$ and $27.7 \pm 1.2 \%$, respectively; $\mathrm{p}<0.05)$. Administration of the vaccine to mice with surgically removed melanoma $\mathrm{B}-16$ led to normalization of this index at the late terms of tumor development (Figure, $b$ ).

Also, the use of XCV demonstrated an activating effect on PM chain of immunity. This is evidenced by an increase of PM counts in vaccinated mice compared with intact and unvaccinated mice with surgically removed melanoma B-16, especially at $32^{\text {th }}$ day after the surgery (by 2.1 times; $p<0.05$ ) and elevation of their CTAl against melanoma $B-16$ cells (Table 3 ).

As it is shown in Table 4, starting from $18^{\text {th }}$ day after surgical removal of melanoma, in vaccinated mice there has been registered significant increase of CTA of SB ( $p<0.05)$, as well as its potentiating effect on PM activity.

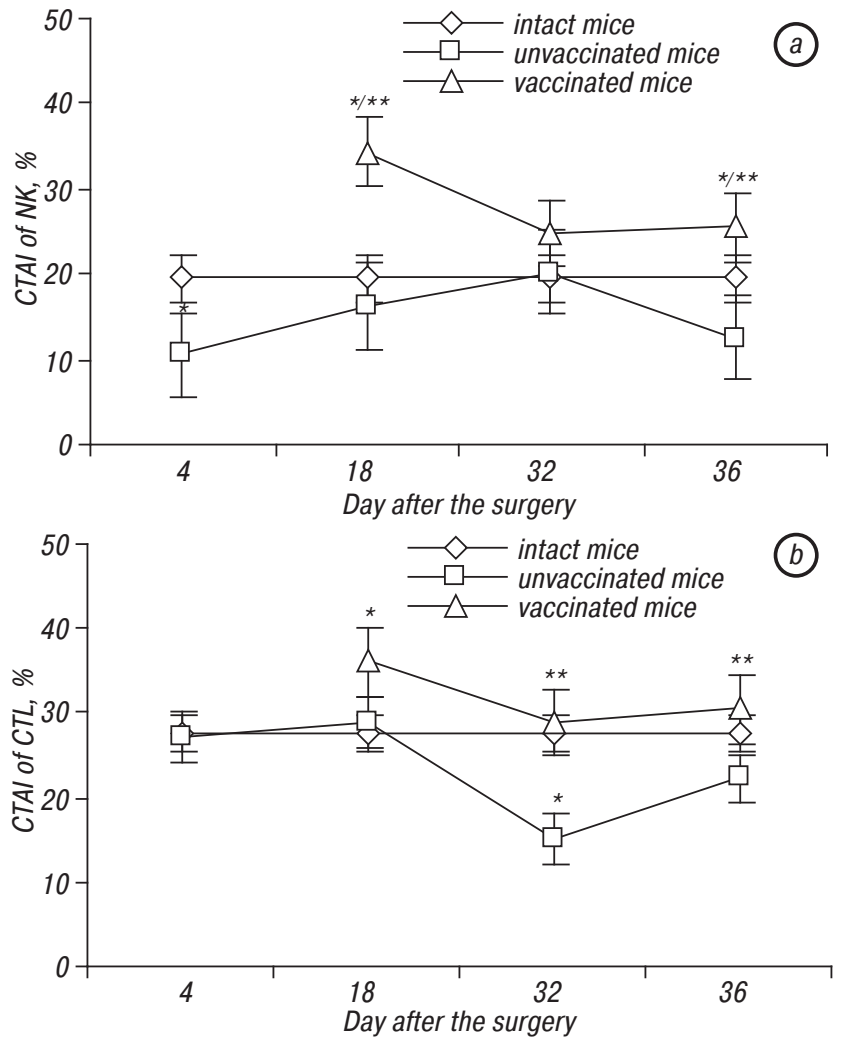

Figure. CTAI of spleen lymphocytes ( $a-\mathrm{NK}, b-\mathrm{CTL})$ in intact, vaccinated and unvaccinated $\mathrm{C} 57 \mathrm{BI}$ mice ( ${ }^{*} \mathrm{p}<0.05$ compared to intact control; ${ }^{\star \star} \mathrm{p}<0.05$ compared to unvaccinated animals)

Table 2. Weight and cellularity of immunocompetent organs and liver of vaccinated and unvaccinated mice treated by surgery removal of B-16 melanoma

\begin{tabular}{|c|c|c|c|c|c|c|c|c|}
\hline \multirow[b]{2}{*}{ Animals group } & \multirow[b]{2}{*}{$\begin{array}{c}\text { Animal weight, } \\
\mathrm{g}\end{array}$} & \multicolumn{4}{|c|}{ Relative organ weight $\left(\times 10^{-3}\right)$} & \multicolumn{3}{|c|}{ Cellularity per $1 \mathrm{mg}$ of organ } \\
\hline & & Spleen & Thymus & $\begin{array}{l}\text { Peripheral } \\
\text { lymph nodes }\end{array}$ & Liver & Spleen & Thymus & $\begin{array}{c}\text { Peripheral } \\
\text { lymph nodes }\end{array}$ \\
\hline Intact & $21.3 \pm 0.8$ & $4.6 \pm 0.6$ & $1.1 \pm 0.2$ & $2.8 \pm 0.4$ & $56.8 \pm 0.7$ & $1.3 \pm 0.1$ & $2.7 \pm 0.4$ & $1.6 \pm 0.2$ \\
\hline$(n=10)$ & $(19.9-24.4)$ & $(3.6-6.8)$ & $(0.6-1.8)$ & $(2.1-4.0)$ & $(53.4-58.0)$ & $(1.03-1.64)$ & $(1.63-3.73)$ & $(1.06-1.97)$ \\
\hline \multicolumn{9}{|c|}{$\begin{array}{c}22^{\text {nd }} \text { day after tumor transplantation } / 4^{\text {th }} \text { day after the surgery } \\
\text { (before vaccination) }\end{array}$} \\
\hline Unvaccinated $(n=5)$ & $18.4 \pm 0.8^{1}$ & $8.5 \pm 1.2^{1}$ & $1.0 \pm 0.2$ & $2.8 \pm 0.3$ & $60.4 \pm 2.0$ & $1.2 \pm 0.2$ & $2.5 \pm 0.3$ & $1.8 \pm 0.2$ \\
\hline \multicolumn{9}{|c|}{$36^{\text {th }}$ day after tumor transplantation $/ 18^{\text {th }}$ day after the surgery } \\
\hline Unvaccinated $(n=5)$ & $21.1 \pm 1.0$ & $8.5 \pm 1.3^{1}$ & $1.1 \pm 0.2$ & $2.9 \pm 0.2$ & $84.7 \pm 3.9^{1}$ & $1.0 \pm 0.0^{1}$ & $2.7 \pm 0.4$ & $1.1 \pm 0.0$ \\
\hline Vaccinated $(n=5)$ & $21.7 \pm 0.7$ & $8.2 \pm 1.9$ & $1.1 \pm 0.0$ & $3.0 \pm 0.2$ & $64.2 \pm 1.7^{1,2}$ & $1.1 \pm 0.1$ & $2.4 \pm 0.2$ & $1.3 \pm 0.1$ \\
\hline \multicolumn{9}{|c|}{$51^{\text {st }}$ day after tumor transplantation $/ 32^{\text {nd }}$ day after the surgery } \\
\hline Unvaccinated $(n=5)$ & $22.2 \pm 0.7$ & $7.9 \pm 0.4^{1}$ & $1.3 \pm 0.2$ & $3.2 \pm 0.5$ & $71.9 \pm 2.0^{1}$ & $1.1 \pm 0.1$ & $2.2 \pm 0.2$ & $1.7 \pm 0.2$ \\
\hline Vaccinated $(n=5)$ & $22.1 \pm 0.5$ & $6.1 \pm 0.4^{2}$ & $1.5 \pm 0.2$ & $3.4 \pm 0.3)$ & $64.0 \pm 2.7^{1}$ & $1.1 \pm 0.1$ & $2.5 \pm 0.2$ & $1.7 \pm 0.1$ \\
\hline \multicolumn{9}{|c|}{$56^{\text {th }}$ day after tumor transplantation $/ 37^{\text {th }}$ day after the surgery } \\
\hline Unvaccinated $(n=5)$ & $16.8 \pm 1.0^{1}$ & $14.7 \pm 1.5^{1}$ & $1.7 \pm 0.8$ & $3.6 \pm 1.8$ & $71.9 \pm 3.8^{1}$ & $0.5 \pm 0.1^{1}$ & $3.8 \pm 1.0$ & $0.6 \pm 0.1^{1}$ \\
\hline Vaccinated $(n=5)$ & $16.2 \pm 0.9^{1}$ & $9.2 \pm 1.1^{1,2}$ & $0.8 \pm 0.2$ & $2.6 \pm 0.5$ & $49.2 \pm 0.3^{1,2}$ & $1.2 \pm 0.1^{2}$ & $1.1 \pm 0.2^{1,2}$ & $0.7 \pm 0.1^{1}$ \\
\hline
\end{tabular}

Note: ${ }^{1} p<0.05$ compared to intact control; ${ }^{2} p<0.05$ compared to unvaccinated animals. 
Table 3. Effect of XCV on PM in intact, vaccinated and unvaccinated C57BI mice

\begin{tabular}{|c|c|c|}
\hline Animals group & Cellularity of PM $\left(\times 10^{6}\right)$ & CTAI of PM, \% \\
\hline Intact & $3.9 \pm 0.2(3.2-4.8)$ & $31.4 \pm 2.7(20.8-41.2)$ \\
\hline \multicolumn{3}{|c|}{$\begin{array}{c}22^{\text {nd }} \text { day after tumor transplantation } / 4^{\text {th }} \text { day after the surgery } \\
\text { (before vaccination) }\end{array}$} \\
\hline vaccinated & & $13.7 \pm 3.4^{1}$ \\
\hline \multicolumn{3}{|c|}{$36^{\text {th }}$ day after tumor transplantation $/ 18^{\text {th }}$ day after the surgery } \\
\hline vaccinated & & \\
\hline ccinated $^{*}$ & & $35.4 \pm 3$ \\
\hline \multicolumn{3}{|c|}{$51^{\text {st }}$ day after tumor transplantation $/ 32^{\text {nd }}$ day after the surgery } \\
\hline vaccinated & & \\
\hline ccinated $^{*}$ & $8.2 \pm$ & $32.1 \pm$ \\
\hline \multicolumn{3}{|c|}{$56^{\text {th }}$ day after tumor transplantation $/ 37^{\text {th }}$ day after the surgery } \\
\hline & & \\
\hline & $5.0 \pm 0.5$ & $37.3 \pm$ \\
\hline
\end{tabular}

Note: * ${ }^{*}$ iven in brackets $\mathrm{Ml}_{\mathrm{ec}}$ compared to unvaccinated animals; ${ }^{1} \mathrm{p}<0.05 \mathrm{com}$ pared to intact control; ${ }^{2} p<0.05$ compared to unvaccinated animals.

Table 4. Effect of SB of intact and treated by surgery removal of B-16 melanoma C57BI/6 mice on CTA of lymphocytes (CTL) and PM

\begin{tabular}{|c|c|c|c|}
\hline \multirow{2}{*}{ Animals group } & \multirow{2}{*}{ CTAl of SB, \% } & \multicolumn{2}{|c|}{ ADCC of: } \\
\hline & & CTL (CTAl, \%) & PM (CTAl, \%) \\
\hline \multirow[t]{2}{*}{ Intact } & $6.5 \pm 1.8$ & $29.4 \pm 2.4$ & $27.6 \pm 2.4$ \\
\hline & & $(18.8-40.3)$ & (16.9-44.2) \\
\hline \multicolumn{4}{|c|}{$\begin{array}{l}22^{\text {nd }} \text { day after tumor transplantation/ } / 4^{\text {th }} \text { day after the surgery } \\
\text { (before vaccination) }\end{array}$} \\
\hline Unvaccinated & $2.2 \pm 0.9$ & $27.6 \pm 2.9$ & $11.6 \pm 3.7^{1}$ \\
\hline \multicolumn{4}{|c|}{$36^{\text {th }}$ day after tumor transplantation $/ 18^{\text {th }}$ day after the surgery } \\
\hline Unvaccinated & & $36.8 \pm 3.2$ & $24.3 \pm 2.1$ \\
\hline Vaccinated $^{*}$ & $20.5 \pm 4.0^{1}(76.7)$ & $28.3 \pm 1.6(-23.1)$ & $30.4 \pm 2.0(25.1)$ \\
\hline \multicolumn{4}{|c|}{$51^{\text {st }}$ day after tumor transplantation $/ 32^{\text {rd }}$ day after the surgery } \\
\hline Jnvaccinated & $19.7 \pm 2.9^{1}$ & $14.2 \pm 4.1^{1}$ & $29.4 \pm 1.5$ \\
\hline & $195 \pm 70(-11)$ & $31.9 \pm 1.9^{2}(124.6)$ & $36.1 \pm 2.9^{2}(22.8)$ \\
\hline \multicolumn{4}{|c|}{$56^{\text {th }}$ day after tumor transplantation/37 $7^{\text {th }}$ day after the surgery } \\
\hline vaccinated & $15.4 \pm 2.8$ & $30.2 \pm 6.4$ & $37.0 \pm 1.2$ \\
\hline Jaccinated $^{*}$ & $31.1 \pm 3.2^{1,2}(101.9)$ & $32.9 \pm 2.2(8.9)$ & $43.1 \pm 1.7^{1,2}(16.5)$ \\
\hline
\end{tabular}

Note: * ${ }^{*}$ iven in brackets $\mathrm{Ml}_{\mathrm{ec}}$ compared to unvaccinated animals; ${ }^{1} \mathrm{p}<0.05 \mathrm{com}$ pared to intact control; ${ }^{2} p<0.05$ compared to unvaccinated animals.

These data showed that administration of the vaccine to mice with surgically removed melanoma B-16 provided preservation (or elevation) of CTA of effectors of cellular anticancer immunity and CTA of SB at the late terms after the surgery, i.e., at the period of intense metastasis. This fact, possibly, could explain significant decrease of the number and volume of metastases in vaccinated animals reported earlier by us [25].

To test this assumption, we have calculated correlation indexes between the indexes characterizing tumor development (the quantity and volume of metastases) after surgical removal of the primary tumors and the abovementioned indexes of activity of cellular anticancer immunity effectors and SB of experimental animals. There has been performed an evaluation of the strength relationship between these indexes and correlation coefficient $r$ by Chaddock's scale [34].

The negative correlation of modulation of the majority of the studied parameters with lung metastasis numbers and volumes has been revealed (Table 5). At $32^{\text {nd }}$ day after the surgery ( $51^{\text {st }}$ day of tumor development) there has been registered the negative correlation between CTA of NK and metastasis numbers (strong; $r=-0.96$; $p<0.05)$ and volumes (good; $r=-0.68)$. At $37^{\text {th }}$ day after the surgery $\left(56^{\text {th }}\right.$ day of tumor development) the correlation between these indexes was strongly negative $(r=-0.88 ; p<0.05$ and $r=-0.95 ; p<0.05$, respectively). Correlation relationship between metastasis indexes and PM CTA remained strongly negative at $32^{\text {nd }}(p<0.05)$ and $37^{\text {th }}$ days after tumor removal. Correlation between CTL CTA and the quantity of me- tastases increased from moderate $(r=-0.33)$ to strong $(r=-0.84)$, and with metastases volumes - from very weak $(r=-0.16)$ to strong $(r=-0.88 ; p<0.05)$. Also there were registered the changes of correlation relationship between metastasis indexes and SB CTA (from weak to good), antibody-dependent cell cytotoxicity (ADCC) of CTL (from weak to moderate) and ADCC of PM (from good to strong).

These data allow suppose that antimetastatic effect of the developed XCV is caused by the increase of CTA of NK and PM and also by preservation of CTL functional activity at the late terms after the surgery. Therefore, the mechanism of action of the vaccine is somewhat different from that of xenogeneic anticancer vaccines developed by Russian scientists on the basis of melanoma cells. Anticancer activity of Russian vaccines is mainly exerted via activation of specific chain of immunity due to the presence of specific melanoma antigens. In particular, has shown the development of prolonged anticancer response in mice with melanoma B-16 vaccinated with human melanoma cells SK-MEL- 1 at the background of increased CTL activity. Activation of specific chain of cell immunity has been also documented in clinical studies when the patients with uveal melanoma were vaccinated with xenogeneic vaccine containing mouse melanoma B-16 cells transplanted into conjunctive tissue capsule $[17,18]$, or when the patients with metastatic skin melanoma were vaccinated with polyantigen cellular vaccine on the basis of B-16 melanoma cells and mouse Lewis lung carcinoma cells [16].

Table 5. Correlation ( $r$ ) between the MI of CTA of EC from vaccinated C57BI mice and metastatic parameters

\begin{tabular}{lcccc}
\hline \multirow{2}{*}{$\begin{array}{c}\text { MI of CTA } \\
\text { of EC }\end{array}$} & \multicolumn{4}{c}{ Metastatic parameters } \\
\cline { 2 - 5 } & \multicolumn{2}{c}{$\begin{array}{c}\text { Number of lungs metastases } \\
\text { 32 }\end{array}$} & \multicolumn{2}{c}{ Volume of metastases } \\
\hline the surgery & $\begin{array}{c}37^{\text {th }} \text { after } \\
\text { the surgery }\end{array}$ & $\begin{array}{c}32^{\text {nd }} \text { after } \\
\text { the surgery }\end{array}$ & $\begin{array}{c}37^{\text {th }} \text { after } \\
\text { the surgery }\end{array}$ \\
\hline NK & $-0.96^{*}$ & $-0.88^{\star}$ & -0.68 & $-0.95^{\star}$ \\
CTL & -0.33 & -0.84 & -0.16 & $-0.88^{*}$ \\
PM & $-0.86^{*}$ & -0.77 & -0.75 & -0.76 \\
SB & -0.47 & -0.70 & -0.22 & -0.57 \\
ADCC of CTL & 0.04 & 0.26 & -0.12 & 0.31 \\
ADCC of PM & -0.68 & -0.50 & -0.62 & $-0.91^{*}$ \\
\hline
\end{tabular}

Note: ${ }^{*} \mathrm{p}<0.05$.

Antimetastatic efficacy of xenogeneic anticancer vaccine developed on the basis of embryonal proteins and products of bacterial origin (B. subtilis) is mostly exerted via activation of effectors of unspecific immunity (PM and NK). Increase of SB CTA against $\mathrm{B}-16$ melanoma cells in vaccinated animals and its potentiating influence on PM could possibly evidence on appearance of some cytokines (in particular, interleukine 1, interferon-gamma (IFN- $\gamma$ ), tumor necrosis factor) in circulation, which provide activation of unspecific immunity as well as preservation of specific immune response at the level of intact animals. It is known that a special role in realization of anticancer response is played by IFN- $\gamma$ produced by T-lymphocytes, NK (upon their contact with TC), and activated PM. This cytokine shows significant immunomodulating action via its influence on practically all EC of immune system [37]. If consider the data on interferonogenic ac- 
tivity of the products of $B$. subtilis [38], the metabolites of which were used for the construction of this vaccine one may suppose that IFN- $\gamma$ and other cytokines may play a role in anticancer effect of the XCV. However, such hypothesis requires further studies.

\section{REFERENCES}

1. Cancer in Ukraine, 2012-2013. Incidence, mortality, performance level of cancer care service. Bull Natl Cancer Register in Ukraine № 15. Kyiv, 2014: 13, 41-2 (in Ukrainian).

2. Monzon JG, Dancey J. Target agents for the treatment of metastatic melanoma. Onco Targets Ther 2012; 5: 31-46.

3. Fil'chakov FV, Korovin SI. Modern approaches to adoptive immunotherapy of metastatic skin melanoma patients. Klin Onkol 2012; 6: 124-8 (in Russian).

4. Agarwala SS. Novel immunotherapies as potential therapeutic partners for traditional or targeted agents: cytotoxic T-lymphocyte antigen-4 blockade in advanced melanoma. Melanoma Res 2010; 20: 1-10.

5. Verdegaal EM, Visser M, Ramwadhdoebe TH, et al. Successful treatment of metastatic melanoma by adoptive transfer of blood-derived polyclonal tumor-specific CD4+ and CD8+ T-cells in combination with low-dose interferon-alpha. Cancer Immunol Immunother 2011; 60: 953-63.

6. Besser MJ, Shapira-Frommer R, Treves AJ, et al. Clinical responses in a phase II study using adoptive transfer of short-term cultured tumor infiltration lymphocytes in metastatic melanoma patients. Clin Cancer Res 2010; 16: 2646-55.

7. Chiang CL, Benencia F, Coucos G. Whole tumor antigen vaccines. Semin Immunol 2010; 22: 132-43.

8. Mikhailova TV, Baryshnikova MA, Klimenko OV, et al. Development of liposomal form of cancer vaccine. Ross Biotherapeut Zh 2011; 10: 62-6 (in Russian).

9. Mikhailova IN, Mikhailova LM, Abramova TV, et al. Preclinical studies of toxicity of cancer vaccine "Melavac". Ross Biother Zh 2010; 1: 57-62 (in Russian).

10. Graf N, Adam C, Mocikat R. Persistence of xenogenized vaccine cells in vivo. Int J Cancer 2003; 105: 217-20.

11. Bergman PJ, Wolchok JD. Of mice and men (and dogs): development of a xenogeneic DNA vaccine for canine oral malignant melanoma. Cancer Ther 2008; 6: 817-26.

12. Seledtsov VI, Seledtsova GV. Xenovaccinotherapy in cancer. Sib Zh Cancer 2010; (3): 48-57 (in Russian).

13. Steitz J, Bruck J, Steinbrink K, et al. Genetic immunization of mice with human tyrosinase-related protein 2 : implications for the immunotherapy of melanoma. Int J Cancer 2000; 86: 89-94.

14. Vollmers H, Birchmeier W. Monoclonal antibodies that prevent adhesion of B-16 melanoma cells and reduce metastasis in mice: cross-reaction with human tumor cells. Proc Natl Acad Sci USA 1983; 80: 6863-7.

15. Barannikova TV. Skin and uveal melanoma: methods of therapy and prophylaxis of metastasis (review) (http://vestnik.rncrr.ru/ vestnik/v11/barannikova_v11.htm) (in Russian).

16. Seledtsov VI, Shishkov AA, Surovtseva MA, et al. Xenovaccinotherapy for melanoma. Eur J Dermatol 2006; 16: $655-61$.

17. Chissov VI, Sergeeva NS, Severin SE, et al. Development of the method for antitumor vaccination of mice into previously incapsulated polyacrylamide gel on the model of mouse melanoma B-16. Mol Med 2004; 2: 24-8 (in Russian).

18. Moskaleva EYu, Rodina AV, Gusakova NV, et al. Induction of melanoma-specific response in mice after xenogeneic vaccination with human melanoma cells injected into Copyright (c) Experimental Oncology, 2015 previously subcutaneously incapsulated polyacrylamide gel. Immunokhimiya 2000; 6: 329-36 (in Russian).

19. Berinstein NL. Enhancing cancer vaccines with immunomodulators. Vaccine 2007; 25: 72-88.

20. Luo Y, Wen YJ, Ding ZY, et al. Immunotherapy of tumors with protein vaccine based on chicken homologous Tie-2. Clin Cancer Res 2006; 12: 1813-9.

21. Seledtsov VI, Felde MA, Samarin DM, et al. Immunological and clinical aspects of applying xenovaccinotherapy in treating melanoma. Russian Oncol J 2006; (4): 23-9 (in Russian).

22. Kaschenko EA. Cellular and humoral mechanisms of tumor specific immunotherapy and their modulation under the influence of hyperthermia. Author Dis Cand Biol Sciences, Novosibirsk, 2009. 22 p. (in Russian).

23. Seledtsov VI, Niza NA, Surovtseva MA, et al. Xenovaccinotherapy for colorectal cancer. Biomed Pharmacother 2007; 61: 125-30.

24. Potebnya GP, Voeykova IM, Yudina OYu, et al. The way to generate cancer vaccine. Patent of Ukraine on useful model № 78756. 25.03.2013, Bull № 6 (in Ukrainian).

25. Voeykova IM, Fedosova NI, Karaman OM, et al. Use of xenogeneic vaccine modified with embryonal nervous tissue antigens in the treatment of B16-melanoma-bearing mice. Exp Oncol 2014; 36: 24-8.

26. Kozhem'yakin YuM, Khromov OS, Filonenko MA, Sayfetdinova GA. Scientific-practical recommendations on animal care and laboratory use. Kyiv 2002, 179 p. (in Ukrainian).

27. Council Directive 2010/63/EU of 22 september 2010 on the protection of animals used for scientific purposes. Official J Eur Commun 2010; L 276: 33-79.

28. Experimental evaluation of anticancer preparations in USSR and USA. ZP Sofyina, AV Syrkin, eds. Moskow: Meditsina, 1980. 79 p. (in Russian).

29. Lymphocytes. Methods. J Klaus, ed. Moskow: Mir, 1990. 395 p. (in Russian).

30. Mosmann T. Rapid colorimetric assay for cellular growth and survival: Application to proliferation and cytotoxicity assays. J Immunol Methods 1983; 65: 55-63.

31. Perederiy VG, Zemskov AM, Bychkova NG, et al. Immune status, principles of its evaluation and correction of immune dysfunction. Kyiv: Zdorovya, 1995. 211 p. (in Russian).

32. Kovbasyuk SA, Yudin VM, Kravchenko SP. Immunomodulating influence of cyclophosphane in different schemes of its administration to mice. Tsitologiya 1985; (3): 31621 (in Russian).

33. Lakin GF. Biometry. Moskow: Vyschaya Shkola, 1980. 290 p. (in Russian).

34. Sydenko AV, Vyshnyakov VV, Isaev SM. Theory of statistics: manual. Moskow: MAKS-Press, 2011. 343 p. (in Russian).

35. Lysenko SA. Analysis of immunological indicators of blood in lung cancer patients with paraneoplastic rheumatic syndrome who have not received special anticancer treatment. Clin Exp Pathol 2013; 12: 109-113.

36. Soroka YuV, Demkiv IYa, Lisnychuk NYe. Markers of endogenic intoxication and state of immune system of white rats at chronic neoplastic intoxication. Tavrich Med-Biol Vestnik 2012; 15: 308-10 (in Russian).

37. Sologub TV, Ledvanov MYu, Maliy VP, et al. Immune response in viral infections. Uspekhi Sovrem Estestvozn 2009; 12: 29-33 (in Russian).

38. Starovoitova SA, Skroitskaya OI. Probiotics on the basis of transgenic microorganisms. Biotechnologia Acta 2013; 6: 34-45 (in Russian). 